\title{
The Ideologies of Production and Consumerism in Belis Tradition
}

\author{
Siti Rodliyah ${ }^{1}$, Andrik Purwasito $^{2}$, Bani Sudardi $^{3}$, and Wakit Abdullah ${ }^{4}$ \\ Universitas Sebelas Maret, Surakarta, Indonesia ${ }^{1,2,3,4}$ \\ $\left\{\right.$ rodliyahs@rocketmail.com $\left.{ }^{1}\right\}$
}

\begin{abstract}
The tradition of giving belis in the marriage customs of Flores people is a condition that is spiritual, cultural, and ideological. The belis tradition has been carried out by the Flores people for hundreds of years. In other words, the tradition of belis has penetrated into a part of the social body, cultural body, and political body in society. Culture studies see the tradition of belis showing the Fantasma of the two ideologies at once, namely: the ideologies of production and consumerism. Belis items such as tusks, gold, woven fabric, livestock, agricultural products or foodstuffs are not only seen as basic necessities. Moreover, the main objects in belis such as tusks, gong, and jewellery are symbolic objects consumed by the public to show their existence in the world. That is, belis items are markers of identity. The capitalist suggestion that surrounds the belis tradition "I am what I produce" and "I am what I consume".
\end{abstract}

Keywords: Belis, Marriage Customs, Flores People

\section{Introduction}

Every community group has a set of values manifested in everyday life. Value is something which seen as valuable and used as a reference for live action and meaning. Values are grown and inculcated through community culture, which is lived as a world of meaning life and discourse and internalized in the world of symbols [1], [2]. In other words, symbols and their meanings are social products intended as social consumption; the product is called culture.

The Flores community has a unique customary wedding culture. The tradition of belis in the traditional wedding ceremony of the Flores community is one of the interesting cultural objects to be viewed from a cultural studies perspective. Belis is seen as the price that must be paid for a girl [3]. Belis has many parts, each of which has its own name and which states a certain number of values. In general view, it can be equated with the term "dowry" or "dowry" which is defined as the amount of money or rights that a prospective husband gives to his future wife in a marriage ceremony, paid in cash or suspended[4].

The term belis appears in the context of the phrase "willitau" from the word "pawilingu" which means spiritual value, social value, and customary law value. The word "willi" in Wewewa is "weli" which means "membeli or buy"[5]. However, some traditional groups insist that there is no "belis" vocabulary in the local language of Flores. Belis should be ideally interpreted and understood as respect for women. Therefore, the family of the male who gives 
the belis will also receive the items in return for the belis from the female family as a commensurate sign of appreciation.

Cultural studies are based on thoughts concerned with the criticism of Marxism. Cultural studies assume that culture is political in a special sense, namely as a realm of conflict and struggle [6]. Therefore, cultural studies require awareness and attention to the details of cultural production, distribution, and consumption. To understand the knitted meanings in people's lives (text or cultural practices), it must be through an analysis of the social context and the history of production as well as their consumption. Cultural studies are seen as important sites for the production and reproduction of social relations in people's lives.

Culture is reproduced by individual and collective actions in identifying with it. In cultural history, cultural compromises have continued to be always relevant to the times and human consciousness. The belis tradition is still deeply rooted in the lives of the Flores people. If the sociocultural phenomenon of the traditional belis is viewed from a critical study, a standard value will be found, namely self-actualization as a primary human need. In a consumerist lifestyle, the motto appears "I am what I consume". This sociocultural reality overturns the pyramid of Maslow's needs. The Flores people demand the existence of belis and commensurate returns not solely for survival. People ask for belis and their replies to actualize themselves as part of an agreed customary empire containing noble values.

\section{Method}

This study was designed in a qualitative-descriptive approach. This typical study qualifies the data collection in sentences, images, and meaningful social realities forms. The qualitative form is expected to be able to provide an in-depth understanding of the social situation under study to seek patterns[7]. The data collection used in this study is through observation, indepth interviews, document studies, and a combination of the three or triangulation. The primary data sources in this study are the resource persons consisting of the community, traditional leaders, and cultural figures. While the primary data in this study are the results of observations, interviews, and the results of study documents. The data analysis technique was conducted interactively through the process of data reduction, data display, and verification[7].

Any reality should be documented, understood as something constructed in various aspects of its importance through cultural and ideological processes[7]. Strinati[8] further emphasized that reality should be analyzed through various kinds of perspectives drawn from structuralism, psychoanalysis, and Marxism, and the appropriate concepts.

Parsons in his book The Social System [9] developed a community model consisting of three systems. First is a social system which was established from human interaction. This is a region that potentially creates conflict, for people to fight over scarce resources and fight for different goals. Second, is the personality system inspired by Freud. The personality system is composed of a number of dispositions of needs, such as preferences, wishes, and desires. The disposition of these needs is compiled by the socialization process and the value system of a society. The disposition setting needs will help protect the social order.

Third is the cultural system. This system leads people to communicate with each other and coordinate their actions, in part by maintaining the expectations of roles as in the social system. There are three regions in applying the cultural system, namely: 1) the realm of cognitive symbols that deal with ideas and beliefs about the world. Activities in this domain are instrumental, 2) expressive symbols that usually communicate emotions (art: music, drama, etc.). To assess it, a set of aesthetic criteria is needed. Activities in this domain are creative and pleasure and 3) standards and moral norms that deal with right or wrong. In this realm, 
value plays a central role. Concrete actions are valued based on their harmony or nonconformity with abstract ideals[1].

The ideologies of production and consumption are closely related to value, more precisely the value of creation. Foucault [10]noted that what someone eats and drinks, what he needs to live, has no value as long as he does not let go of it; and what he doesn't need equally nullifies value as long as he doesn't use it to get what he needs. In other words, something can represent others in exchange, they must exist as bearers of value; and while the value is only in representation, i.e. in exchange or ability to be exchanged.

There are two simultaneous ways to interpret the problem. First, analyze the value in the exchange action itself, at which points are given and received crossed. Second, analyzing the value as part of the exchange and as a primary condition without exchange it cannot be done. The first reading is closely related to analysis that puts all essence in a proposition. The second relates to an analysis which gave birth to the essence of the same language which is located in the area of primitive marking. The theory built by Foucault (2015) will be operated in this study.

\section{Result and discussion}

Woven Fabrics, Food Ingredients, and Animal Animals as a Production Ideology in the Belis Tradition. Production is one of the popular culture characteristics. Modernism is characterized and interpreted by what one can produce. That is, by producing goods, humans create meaning for their lives. Whereas postmodernism raises the ideology of consumerism, which means that humans create meanings for what they consume. They consume cultural symbols. Third world countries, developing countries, have not yet finished with modernism. However, third world society or developing countries are still affected by what is called postmodernism.

Belis and its replies are among the lifestyle samples of the production and consumer society. Flores women should at least prepare themselves to join her husband's clan. This tradition is still held firmly by Flores women. Refusing this means fighting parents, against customary law. In the Freudian view, fear of being punished and desiring approval, causing a girl to identify herself with moral measures from her parents. Identification with parents results in the establishment of superego [11].

Belis or bride price is commonly prepared by the Flores community in traditional wedding ceremonies are elephant tusks in their varying lengths and numbers, gold jewelry, woven fabrics, livestock, and agricultural products. In addition to elephant tusks, all objects of the belis are products of human production. The Flores community produces food from agriculture. Pig farming is also growing rapidly in Flores. Jewelry craftsmen have also spread in every corner of the city whereas weaving cloth is a product of Flores women's hand.

In ancient times, livestock which most often used for belis were those of horses, buffaloes, pigs, goats, chickens, and ducks. For today's more practical people, all of these animals are simply replaced with a certain amount of money, as well as jewelry and various food and grain ingredients. Livestock that can still be found in a series of wedding ceremonies is pigs and goats. These animals are used to entertain guests at wedding parties. Although religious institutions have offered cheaper and more practical marriage processions, the Flores community still tries to run old customs. Marriage must be welcomed with a party. The principle is closely related to family and clan dignity. The bigger the party is held, the higher the prestige received. 
Flores women produce various types of woven fabrics for various purposes. Weaving activity has become a tradition rooted in Flores women. In other words, weaving is one element of Flores women's integrity. The weaving activities that have been going on for generations have finally emerged as a form of ideological production in the cultural genealogy of the Flores people. Quality woven is normally priced with a high value so it is suitable to be exhibited. In addition to the wearer or buyer, women who work woven fabric will gain popularity. Although woven fabric production has been transformed as an ideology, it cannot yet be used as a measure that the Flores community has turned into a fully modern society.

In case the Flores women suddenly quit producing woven cloth, they may feel lost in their identity, even their social bodies will be chaotic. The social body that the researcher intends to explain is a set of values, rules, and norms limited by the community so that they display the community's fantasy of identity. When the production (woven fabric) has become an ideology, this activity in chained with the social body of the respected society. In a similar case, Sartre [12] emphasized that if a person has changed to someone else and suffers from the continuous absence in the depth of her existence, that person will feel this absence is as if the absence is another person: the other person is no more present rather than herself. In short, a person will experience alienation in herself.

The Flores women who are maintaining to produce woven fabrics are not solely guarding their cultural symbols. Moreover, woven fabrics production activities are closely affiliated with economic factors. In philosophical studies, the two layers of the discourse are often reversed; weaving activities that are affiliated with the economy are fantasies of the highly respected cultural meaning 'adi luhung'. Flores women actually do not just create a piece of fancy woven fabric. They are pinning myths, legends, imaginations, and fantasies on their woven fabric. That is, producing woven fabric is a mythic repetition activity; remembering that woven fabrics with certain motifs (animals) are clothes that are usually only worn by traditional groups of past nobles. In other words, weaving cloth is an act of reproducing myths. These skills in production make Flores women must be highly valued in marriage.

Producing woven fabrics with particular motives is one way of being. Producing woven fabrics is used as a sign by which Flores women conduct research and are judged by others. In the case of woven fabric production, Flores women are contesting woven quality. This view is based on information that in the production process of woven fabric, there are coloring techniques that hide as company secrets. In the past, the owners of production materials were noble women. These noble women are taught how to make motives. Whereas ordinary women are only positioned as laborers who are not equipped with the ability to create motives. Therefore, the dichotomy of the bourgeoisie and workers is very prominent. Along with the times, working-class women and noble women began to compete in producing woven fabrics.

Flores women who do not have access to modern financial regulations still have to carry out the old way, namely to produce sheets of woven fabric that have not been patterned. They do the work under the authority of the manufacturer. For women who have worked in companies, traders, teachers, nurses, civil servants, usually no longer carry out activities to produce woven fabrics. However, those who are still bound by customary rules transformed from adherents to production ideology become the loyal adherents of the consumerist ideology.

Elephant Tusks, Gold Jewelry, Livestock, Food Materials, and Woven Fabrics as the Consumerist Ideology in the Tradition of Belis. Consumption emerged as a cultural concern in the late 1950 s and early 1960 s in the western world as an anti-thesis against production. Analysts focus on the consumer community. It was only in the 1970s that studies of consumption society became very evident in cultural studies. Various subcultures provide a variety of commodities to produce alternative and opposition meanings. Recently, 
consumption was also found in studies of fan culture and pop culture. Adian further explained that the Frankfurt accused capitalism of continuing to work culturally to paralyze the critical mind of society through a consumeristic lifestyle. They alleged that a consumeristic lifestyle had integrated the labor and bourgeois lifestyles [13](cited in Adlin (Ed.), 2006: 25).

There are times when cultural capitalism subtly shapes totalitarianism in a consumeristic society. Finally, society has almost no freedom in determining its lifestyle. This can be further interpreted that everything is external pressure, namely power and capital (money) that work in a Utilitarian manner. Of course, the results of analysis like this, which is based on the thinking of the Frankfurt intellectuals, like Habermas, will hurt the feelings of the people who practice customary law. However, totalitarianism can hardly be achieved by a family of men who are not enough to provide belis. This means that customary law as lifestyle domination has never been total conduct. Lifestyle (culture) in the end is not a place of domination, but rather as a venue for contestation.

A man who wants to propose a girl must provide a belis. From time to time and from various indigenous territories in Flores, belis in traditional customs in the form of elephant tusks (in various sizes and quantities), knives (keris), Gold jewelry, gongs, horses, pigs, goats, food, agricultural products, and cash. There is one indigenous area that provides tusks of belis for rental. Belis can literally be owed, and the debt is borne by the offspring if it is not paid off At first glance, the capital burden for holding the belis looks heavy for the middle to lower economic community. This objection was immediately closed with the argument that women have high value or value.

Elephant tusks, gong, gold, and parties are items consumed by Flores people. Eating those objects becomes a marker of their social identity. These rare and expensive symbolic objects are born from the arena of cultural production. The arena of symbolic production and circulation is defined by Bourdieu as a system of objective relations between different agencies functionally defined by their role in the division of labor of production, reproduction, and distribution of symbolic goods [14]. The arenas of cultural production are born out of opposition between the limited production arena (producers) and society. The limited production arena tends to retain its own criteria for obtaining cultural recognition from peer groups whose members consist of clients and competitors.

The limited and scarcity of the number of tusks on Flores, according to economic principles, resulted in increasingly expensive tusks prices on the market. Then, in some areas, tusks belis do not need to be tangible. Simply replace it with a number of money that is adjusted in value with the price of tusks on the market. In this case, tusks will then only be limited consumption of the elite. High-quality woven fabrics are also used as a marker of social class. In the end, the social class markers were no longer measured by castes like the past but from financial strength. The tradition of giving belis and replies is usually borne by male family clans and female family clans. The Flores community still upholds the spirit of mutual cooperation. The consequence of this clan's involvement is the swelling of the costs of customary wedding ceremonies. In the tradition of belis, because it involves a clan, clan's selfesteem is an important consideration in every detail of the marriage procession. The bargain amount of belis often takes place a lot. Bargaining the amount of belis is related to the amount of retaliation that will be received and practice obtained by the female family clan and the male family. That is, the belis born from the arena of limited cultural production has manifested itself as a marker of identity as well as a manifestation of the consumerist ideology.

Marcuse clearly criticizes that consumerist ideology promotes false needs and that these needs work as a form of social control: "those people recognize themselves in their commodities ..." (cited in Storey, 2010: 145). The consumerism ideology instills suggestion 
that life meaning must be found in what we consume, not in what we produce. Consumption is used to mark unique and differences. In the social phenomenon the belis tradition: "I am what I consume", shows one's social class in society. The symbolic exchange in the tradition of belis, borrowing the term suggested by Paul Willis[15], is grounded aesthetics. The community seeks cultural understanding of the world by attaching meanings to various symbols and practices, then selecting them again, highlighted, rearranged to produce more precise and distinct meanings (1990: 21).

Although the existence of belis is essentially a debate among the wider community, a number of social groups who object to the tradition of belis try to make cultural compromises. The offer given by religious institutions (both Christianity and Islam) in terms of marriage at first was like a subcultural consumption pattern. People who are not able to provide belis, will choose to walk on the path provided by religious institutions. They tend to celebrate extraordinary things as opposed to the ordinary, namely traditional customs. The Catholic Church addresses this social phenomenon by acculturating local culture with a set of church rules regarding marriage. Acculturation between church rules and customary law, in some marriages, is used by the elite to show their social position. After holding a wedding ritual in the church, the elite class still held a series of traditional wedding traditions which were closed with a large party that lasted for days.

\section{Conclusion}

The belis and its replies tradition is a typical lifestyle of the people of production and consumption. Nevertheless, the lifestyle was still dominated by the bourgeoisie which characteristically controls capitalism, such as the means of production, raw materials, and money. The tradition of belis initially regulated the indigenous marital structure of the community based on its social strata. However, in its development, the tradition of belis is no longer discourse on the dominance of customary rules, but rather on social class contestation. The belis tradition in culture studies perspective reflects two ideologies at once: the ideology of production and the ideology of consumerism. Both ideologies are born from the arena of limited cultural production which aims to find identity or identity. Removing the belis tradition will result in the alienation of individuals as well as collectives. Behind all that, traditional traditions contain a spirit of struggle for feminism which is believed to be a great value by the people of Flores. At a later stage, the belis tradition teaches Flores youth to actively work to collect money before they decide to settle down. However, given the large amount of capital that must be collected by a man who wants to get married, the tradition of belis always leaves a trail of conflicting arguments between the pros and cons.

\section{References}

[1] M. Sutrisno and H. Putranto, Teori-Teori Kebudayaan. Yogyakarta: Kanisius, 2005.

[2] B. Busro and H. Qodim, "Perubahan Budaya dalam Ritual Slametan Kelahiran di Cirebon, Indonesia," J. Stud. Agama dan Masy., vol. 14, no. 2, pp. 127-147, Sep. 2018.

[3] P. Arndt, Masyarakat Ngadha: Keluarga, Tatanan Sosial, Pekerjaan, dan Hukum Adat. Flores: Nusa Indah, 2009.

[4] H. G. Abdurrasyid and A. F. Hidayat, Kamus Bahasa Arab (Kontekstual Aplikatif). Bandung: Pustaka Setia, 2008. 
[5] B. Anggraeni and Y. Kalunga, Perempuan Sunda dan Belis. Sumba: Bidang Penelitian dan Pengembangan BAPPEDA Pemerintah Kabupaten Sumba Timur, 2003.

[6] J. Storey, Pengantar Komprehensif Teori dan Metode Cultural Studies dan Kajian Budaya Pop. Yogyakarta: Jalasutra, 2010.

[7] Sugiyono, Metode Penelitian Kuantitatif, Kualitatif, dan Kombinasi Kombinasi (Mixed Methods). Bandung: Alfabeta, 2016.

[8] D. Strinati, Popular Culture: Pengantar Menuju Teori Budaya Populer. Yogyakarta: Bentang, 2004.

[9] T. Parsons, The Social System. New York: Free Press, 1951.

[10] M. Foucault, The Order of Things An Archaeology of the Human Sciences. Yogyakarta: Pustaka Pelajar, 2015.

[11] C. S. Hall, A primer of Freudian psychology. USA: Pickle Partners Publishing, 2016.

[12] J. P. Sartre, Seks dan Revolusi. Yogyakarta: Narasi, 2016.

[13] A. Adlin, Resistensi Gaya Hidup: Teori dan Realitas. Yogyakarta: Jalasutra, 2006.

[14] P. Bourdieu, Arena Produksi Kultural: Sebuah Kajian Sosiologi Budaya. Bantul: Kreasi Wacana, 2010.

[15] P. Willis, Common Culture. Milton Keynes: Open University Press, 1990. 